\title{
The Village of the Year Competition Constructing an Ideal Model of a Rural Community in Finland
}

\author{
Ka isu Kumpula inen
}

\begin{abstract}
The Village Action Association of Finland (SYTY) organizes the Village of the Year competition annually to award active rural communities. The competition has taken place since 1985, but after the village action movement was integrated into Finnish rural policy networks in the 1990s, it also became a part of rural policy instruments. The competition can be considered a governing technique that constructs norms and an ideal model for rural communities to pursue. In this article, I study the representation of an ideal rural community by analysing the criteria of the competition. I also look for changes to see whether the integration of the village action movement into rural policy is reflected in the norms and representations of ideal rural communities. The results show that an ideal rural community consists of five characteristics: strategic planning, development projects, responsibility for local welfare, cherishing cultural heritage, and village spirit. They also reveal that the requirements for active villages have expanded, which reflects the increasing responsibility of communities for service provision and local development in rural areas.
\end{abstract}

KEY WORDS Rural community, village action, active citizenship, government, representation of rural

\section{Introduction}

The Village Action Association of Finland (SYTY) organizes the Village of the Year competition annually, in which it awards the most successful village in Finland. The competition started in 1985 with the aim of increasing publicity for the village action movement and respect for rural community development (SYTY Bulletin 1985). When the first Village of the Year was elected, the election criteria were the following: "The village has set a good example with its active endeavour to improve local living conditions and comfort" (SYTY Bulletin 1/1985). The competition has succeeded in its mission; the awarded villages receive a lot of public attention and become role models for Finnish rural communities (Hyyryläinen 1994: 74).

The village action movement was established in the 1970s to increase the sense of community and the availability of services in declining villages. The number of village associations has steadily increased, and in 2013 there were 3,074 village associations in Finland, covering most of the villages in the country (there are 4,235 villages in Finland). The establishment of a village association has become the key instrument to organize social activities in Finnish rural communities, and it is commonly seen as an effective instrument to turn local

Sociální studia / Social Studies 2/2016. Pp. 55-71. ISSN 1214-813X. 
development in rural communities from decline to prosperity (Kumpulainen 2012). The lack of public services emphasizes the role of non-governmental organizations, such as village associations, as organizers of local activities in villages. They maintain and renovate community halls, organize events and recreational activities and maintain outdoor facilities. Village associations receive no permanent financial support from the state or the municipality, but their income comes from the associations' own fund raising and European Union project funding (LEADER).

A significant turning point for the movement was when it was integrated into national and European Union rural policy strategies and networks in the 1990s (Hyyryläinen 2000). The Village Action Association of Finland (SYTY) was established in 1997, and it replaced the earlier Village Advisory Board (KAN). The establishment of the new organization helped to strengthen the structures of the village action movement. SYTY consists of regional associations and local action groups organizing European Union community development funding (LEADER) (Halhead 2004: 14-15). The integration of the village action organization with rural policy resulted in a more strategic approach, establishment of national village action programmes, increased development project funding and more strategic development projects at the local level. SYTY has started four national rural community development programmes since the year 2000 in which it has defined general objectives and principles for rural community development in Finland.

The institutionalization of the village action movement at the national and regional levels was reflected also in practices in rural communities. Since the 1990s, most unofficial village committees have been registered as associations, and their development activities have become more strategic. The establishment of regional-level village associations, in turn, affected the organization of the Village of the Year competition. The election of the provincial winners was made part of the provincial village associations' responsibilities in the 1990s. Winners at the provincial level participate in the national competition, which means that today the competition is organized in two phases, and village associations are no longer able to participate directly in the national Village of the Year competition. The reform has also increased regional visibility and the total number of participants in the competition.

The Village of the Year competition is an essential part of SYTY's functions, and it reflects the values and changes in the village action movement. The integration of the village action movement into Finnish rural policy also makes the competition a part of rural policy and an instrument to promote its objectives. The competition produces and spreads the representation of an ideal rural community according to rural policy objectives, establishing norms that every village should adopt and follow. In rural policy, the main objective is to keep rural areas viable and prosperous through diverse development activities. There is an emphasis on place-based initiative, and for rural people this means that they are encouraged to take a more active role in developing their local communities. This is reflected in the norms of village action and also in the criteria of the Village of the Year competition.

The aim of this article is to study the representation of an ideal rural community produced by the Village of the Year competition. Rural reconstruction (Woods 2005), i.e. changes in practices and representations of rurality, is also reflected in how rural communities are constructed and produced as rural space. This makes it important to study the direction 
the transformation of rural communities is taking and how these changes are related to policy-level objectives. In this article, I explore what kinds of characteristics the representation of an ideal rural community comprises. The data of the study consist of the questionnaires and portraits of the winners during the years 1985-2007 as produced by SYTY. I have also looked for changes in the criteria to find out whether the integration of Finnish rural policy and the village action movement is reflected in the representation of an ideal rural community.

\section{The Ideal Model of a Rural Community as a Goveming Technique}

The "cultural turn" in rural sociology and geography since the 1990s has turned the field's focus towards cultural and social representations of rurality (Bell 2006; Cloke 1997; Little 1999; Pospěch et al. 2015). The cultural approach has revealed the complex character of rural space (Halfacree 2006; Jones 1995) by increasing knowledge of diverse meanings and perspectives related to rural places and areas. There have been studies concentrating, for example, on policy representations (Gray 2000), media representations (Lagerqvist 2014; Vepsäläinen and Pitkänen 2010), and local representations (Halfacree 1995; Jones 1995) of rural space. Positive representations of rurality have been studied especially in relation to "rural idyll", i.e. to the mythical and normative image connected with rurality (Lagerqvist 2014; Pospěch et al. 2015; Vepsäläinen and Pitkänen 2010). Even if the existence of the rural idyll has been questioned by several studies (for example Little 1999), it is still present in media representations and also in local people's descriptions (Jones 1995; Vepsäläinen and Pitkänen 2010). Especially when the countryside is constructed as an attractive place for tourists or consumers, the image of the rural is built through reference to a nostalgic past.

In addition to rural space, communities are also idealized in popular representations. According to Joseph (2002), communities are romanticized in different fields of society, and she criticizes the way the idealization of communities as something unequivocally positive legitimizes inequality and social hierarchies in society. The Village of the Year competition also idealizes communities and produces a representation of an ideal community which is a specific representation of the rural idyll, portraying local rural communities from a particular normative perspective. Pospěch et al. (2015) have studied the images of a good village constructed by the competition in the Czech Republic. Their research concentrated on analysing the pictures through which competition participants present their communities when trying to convince the judges of their excellence. The results show that the representation of a rural community is more complicated and multi-dimensional than the timeless and peaceful rural idyll. Rather, according to their study, the image of a good village emphasizes the social and everyday life of local people. The social dimension is obviously an important element when studying representations of communities, and the more interesting question is how the social is represented and with which other elements it is connected. In the Czech case, local activeness was a central defining criterion for a good village, a criterion that also plays a significant part in representing the social dimension in the representations of an ideal rural community in Finland.

Representations of the rural idyll involve the question of power, in other words, whose values and meanings are included in the images and whose voices are marginalized 
or excluded (Cloke and Little 1997). It also makes the representation of an ideal community a way of governing communities by constructing norms and values for local community action. The Foucauldian concept of governmentality (Dean 1999; Foucault 2002) is a useful theoretical approach when interpreting the connections between diverse local and policylevel processes. Governmentality concentrates not only on state policies but consists of all the rationalities and practices through which citizens are governed. The concept of governing technique refers to all practices and instruments that direct and control individuals' behaviour, including those not consciously used as instruments of power. For Foucault (2002), power is present in all social interactions and processes, and governing cannot be seen only as something practised by state authorities.

The Finnish village action movement is a part of a global trend in the government of rural areas. In recent decades centralized state policy has been questioned and the role of civil society actors emphasized in rural development (Krawchenko 2014; Ray 2000). Different kinds of "bottom-up" and community-based approaches are examples of how individual citizens and communities can be activated to take more responsibility for local development and living conditions (Cheshire, Higgins and Lawrence 2006; Eversole 2010: 30; Herbert-Cheshire 2000). In modern societies, subjects are governed as citizens, a condition which emphasizes how people are constituted and how they constitute themselves as moral and responsible subjects (Dean 1999: 67-79; Foucault 1981; Marinetto 2003). Cruikshank (1999) talks about technologies of citizens in liberal democracy, i.e. how practices of community involvement construct a certain kind of subjectivity that is not so dependent on the state (Marinetto 2003). Community development and village action can be seen as self-technologies constructing self-governing and responsible citizens in rural areas (Herbert-Cheshire 2000; Triantafillou and Nielsen 2011).

The government of citizens is based on knowledge: how people, processes, and places are defined and problematized. Governing produces norms, problems, and ideals according to the prevailing governing rationality (Gordon 1991). Village action is a particular method of organizing local action in Finnish villages, and it is related to a broader rationality of government of active citizenship politics and rationality (Gaynor 2011; Kearns 1992). The objectives of educating about active citizenship through village action and of increasing the responsibility of local communities are explicit in Finnish rural policy (The National Village Action Programme 2003-2007: 47). The state encourages village associations to take more responsibility in promoting welfare in rural areas, for example through project funding, and at the same time centralizes public services in larger units, which means transferring the responsibility of the state to self-governing local communities (Herbert-Cheshire 2000).

In active citizenship politics, there is an objective to make individual citizens more responsible for their own welfare by reconstructing them as members of active communities (Rose 2000). Many of the village associations in Finland are examples of active communities in rural areas taking responsibility for local development, for example by taking care of village halls, managing different kinds of development projects, and writing village plans. In the context of rural communities, rationality means ways of reasoning that define the norms and objectives for rural community development; in other words, what a good village is and how communities should develop themselves. For Finnish villages, being an active village 
is the ideal situation (Kumpulainen 2012). The Village of the Year competition is one instrument through which the policy level gives recognition to active rural communities and also tries to activate other rural communities to adapt their community development practices. It is turned into a governing technique for promoting active citizenship politics.

The criteria of the Village of the Year competition correspond to the governing rationality and the norms of rural community development. The media portraits of the winners construct representations of ideal rural communities, and individual members of the awarded villages are portrayed as active citizens who show their activeness by practising specific activities, such as village planning, project work, and maintenance of village halls. Even if represented as unquestioned truths, the norms are the result of political choices, such as which characteristics of rural communities are represented as desirable and which are seen as obstacles for local progress. The winners in the competition receive a lot of publicity and media attention, which spreads the message of rural policy to a wider audience and to other people living in rural areas.

In the media representations of the ideal models, the prevailing norms and governing rationality of rural community development become personalized and concretized. The portraits of the Village of the Year winners offer people living in declining rural communities hope by presenting success stories and examples of how to survive and build a more positive future for their villages. According to Rose (1990: 243; see also Klesse 2007), the "power of the image" is an effective instrument of governing because images give individuals something against which they can evaluate their own history and experiences. The portraits of the winners build idealistic images and representations of rural communities by showing only the bright side of community development practices, and they also reproduce the rural idyll by romanticizing local communities as ideal places to live.

\section{Methodology and Data}

The data of the study consist of the national Village of the Year competition questionnaires filled in by the participating villages and of the portraits of the winners published in the Village Action Association of Finland's (SYTY) bulletins (before the national association was established in 1997, the bulletins were published by its predecessor, the Village Advisory Board). The data collected cover the time period from the beginning of the competition in 1985 to the year 2007. The number of villages participating in the national competition stabilized in the 1990s, when only the regional winners chosen by the provincial village associations were allowed to take part in the competition (there are 19 regional village associations in Finland).

My analysis has consisted of two stages. First, I have analysed all the questionnaires from between 1985 and 2007, and by applying content analysis constructed a classification of the characteristics of an ideal rural community on the basis of individual competition questions. The filling in of the form is an important element in succeeding in the competition, as the jury does not visit the participating villages. This means that the questionnaires are comprehensive and the awarded villages must be competent in expressing their excellence in writing, and in marketing themselves. On the basis of the questions presented in 
the questionnaires, I identified five different characteristics that an ideal village should have. They are strategic planning, development projects, responsibility for local welfare, cherishing cultural heritage, and village spirit. The same themes can be found through the years, but there have been changes within the individual characteristics over time.

In the second stage of the analysis, I have studied all the portraits of the winners published by the national village action organization since the start of the competition (22 in total) on the basis of the five characteristics recognized in the first stage of the analysis. Through discursive reading I have analysed how the winners, and the qualities of the rural communities, are represented, and whether there have been changes in the descriptions during the period under study. The analysis is based on the rhetorical assumption that the portraits are published not only to give information about the competition and the winners, but they constitute a form of persuasive argumentation (Perelman 1982) aimed at convincing the audience of the representations and to adopt them as unquestioned truths. The publisher always makes choices about which practices and features to include and exclude from the winners' portraits. The announcement of the ideal rural communities is part of an effort to bring forward and emphasize particular practices and values of village action, which affects how the villages are represented in the portraits. I have also looked for changes in the representations of ideal villages over time to see how the integration of Finnish rural policy and the village action movement in the 1990s has been reflected in the criteria of an ideal village.

\section{Results: The Criteria of an Ideal Rural Community}

\section{Strategic Planning}

Strategic village planning has been an essential part of village action from the beginning of the movement, and it is also a criterion in the Village of the Year competition. An ideal rural community has written a village plan and also has a strategic approach towards all local activities.

The argument for the award was that the villagers have jointly and consistently developed Vähähaara with long-term aims on the basis of local tradition. (Bulletin 1/1990)

In the portraits, the development of villages is described as "systematic" and "purposeful" action. Planning is an instrument to build a village's future, and in the competition it is a concrete indication and manifestation which shows that the village association and local people are committed to develop their community. Following the increasing number of development projects in the 1990s, the role of village plans has been emphasized as a part of project work. If village associations want to apply for European Union (LEADER) funding for their projects, they also need a documented village plan.

Village plans can include very different kinds of objectives. They may concern building or renovating village halls and other buildings, organizing events and fests, development projects, stewardship of landscapes, improving the water system or roads, or developing new livelihoods and services. The content of village plans has expanded in the 2000s and there are new fields to be included in village plans, for example land use, business, and security 
planning (The National Village Action Programme 2008-2013). This entails an increasing range of responsibilities for rural communities to take care of by themselves.

Village planning is not only rational or even planning per se, but an instrument for villages' self-reflection and construction of a community identity. SYTY provides villages with instructions on how to prepare a village plan (Village Plan Guide 2002):

- Why do we draw up a village plan

- Our village now

- The facts

- The spirit and atmosphere in the village

- The strengths, resources, and potentials of the village

- The weaknesses, problems, and risks in the village

- History: how did we get here

- Shared vision and objectives

- How the world situation affects our village

- Future options

- Ideas

- Actions

- Process - compilation, monitoring, updating

These instructions are reflected in the portraits of ideal rural communities. The winners are represented as successful in identifying their strengths and resources, and using them to change the village's negative trend to a successful future. Representing the features of a village as something to be evaluated and worked on emphasizes the community's own responsibility for local development (Herbert-Cheshire 2000). Villagers should avoid the risks, make use of their strengths, and reform the village atmosphere so that a positive change can be achieved.

There are many possibilities in rural areas if only there is competence to make use of them. Rannankylä has been able to do it successfully, the election jury concluded. (Bulletin 4/1991)

The success of a village is constructed as a result of the village association's own ability and motivation to develop and change itself. The community's internal factors are the key to success or the cause of decline - not structural, political, or economic factors in society at large. The definition of a village's past and present, and strengths and weaknesses, is a concrete practice of self-reflection, constructing "us" and the community identity. According to Foucault (1981), this can be considered a confession ritual in which communities reflect themselves in relation to prevailing knowledge, truths, and norms (Herbert-Cheshire and Higgins 2004). In Finnish villages, this means that subjects internalize "who we are" according to the prevailing governing rationality, which in the case of rural communities is the community development discourse. Village planning is a combination of both rational and strategic planning, and deep self-reflection and a confession ritual, which makes it an effective governing technique in constructing active communities. 


\section{Development Projects}

Development projects has been a selection criterion in the Village of the Year competition from the 1980s, but since project funding increased significantly after Finland joined the European Union in the 1990s, its importance has become even more pronounced. For example, in 2010, 38 million euros were spent on village development projects in Finland (SYTY homepage). The increased funding has meant more and bigger development projects in rural areas. Village projects have mostly concerned the renovation of village halls and other public spaces, environmental management, writing village books, and organizing different kinds of events and local services.

In the winner portraits, strategic development work is represented as the key to success and the main instrument to save villages from decline. They include descriptions of how local people have a strong belief in development projects and see them as a way to keep rural areas flourishing.

Pentti Sarja and Jaakko Hautamäki assure that the projects under discussion will guarantee that the village school will stay in the village and that there will be new residents. (Bulletin $1 / 2002$ )

In the bulletins, development projects are also constructed as a manifestation of villages' power; they demonstrate to visitors what has been achieved by the communities' own action. In the competition questionnaires, the projects are defined as the villages' "displays of strength"; as the outcomes of local activeness (Bulletin 5/1997):

What are the three most significant displays of strength in Santtio during the last five years?

1. The Pyhäranta event: a traditional summer festival, 3,000 to 4,000 visitors in three days

2. The Santtio wooden village action centre, budget 1.5 Finnish marks

3. The collection of local tradition, a peasant sailing book and a village book

The quotation indicates that the "displays of strength" are evaluated quantitatively, which increases the plausibility of the argument. The number of visitors, budgets, and calculation of voluntary work hours are indicators that show how significant the results of community work are.

The Rämsöö village has always followed the principle that before they start any event they make detailed profitability calculations, a risk analysis and long-term plans. (Bulletin 6/2007)

Rural community development work is one example of the increasing role of money and calculations in different areas of life (Rose 1999: 197-232). Project work transforms voluntary work into something that has to be measured and accounted for to evaluate its efficiency. The new logic is in conflict with the traditional idea of community effort, according to which people should not calculate the hours they work for their neighbours' welfare. It changes rural communities so that they adopt a more entrepreneurial attitude in organizing local action (Herbert-Cheshire and Higgins 2004). In addition to calculations, development projects also bring bureaucratic practices to rural communities. Development projects involve a great deal of bureaucratic work: writing applications, keeping the accounts, reporting about the project, etc. These less pleasant practices of project work are not mentioned in the portraits 
of the Village of the Year winners, even though they take a lot of time and people find them frustrating (Kumpulainen 2012).

Traditional voluntary work in rural communities has become entangled with new kinds of practices and techniques that require from and teach citizens particular skills and competences (Herbert-Cheshire 2000). The increasing role of projects over the past decades is part of the change in governing by which different kinds of projects have become symbols of efficiency and innovation (Sjöblom and Godenhjelm 2009). Herbert-Cheshire (2000) talks about entrepreneurialism in rural communities, how rural community development requires adoption of the attitudes and values of an entrepreneurial culture, which is also reflected in the representation of an ideal rural community. Village projects encourage active citizenship, not only by changing the nature of community action, but also by increasing communities' concrete responsibilities in rural areas. For example, renovated village halls and other public places have to be maintained after the project with self-financing and voluntary work.

\section{Responsibility for Loc al Welfa re}

An ideal rural community is expected to promote the welfare of its residents by developing local services and livelihoods.

What actions have been made to improve the villagers' living conditions: Work and livelihood? Housing and living environment? Training opportunities? Leisure and culture? Commercial services? Roads and traffic? Social activities? (The competition questionnaire 1987)

How have the village and the villagers been involved in the development and protection of local services, e.g. village shop, school, post office, village service centre, village assistant, transportation services? What projects related to the development of livelihoods has the village been involved in implementing over the past five years? (The competition questionnaire 2007)

In 1987, the emphasis in the questionnaire was not so clearly on villages' own activeness in providing services, and the services produced by the municipality or the state were also considered worth mentioning. But in 2007, there were only questions about those services that were provided by the villages' own activeness and their involvement in development projects. The change reflects the increase in the role of communities and individual citizens in providing services in rural areas. If the municipality or the state does not provide local services, ideal rural communities produce them by themselves. The portraits of the Village of the Year winners include descriptions of how village associations take care of and develop local services in different ways.

In the Village of the Year 2005, Heinola, thanks to the development project concerning the village hall, the village association succeeded to stop the decline of local services caused by the municipality merger. (Bulletin 5/2005)

According to Finnish rural policy, project funding is the main instrument to develop different kinds of models to secure services in rural areas (The Rural Development Programme 2007-2013 for Mainland Finland: 190). Cooperation between different stakeholders is a central part of taking responsibility for local welfare, and it is also a criterion for the election 
of the Village of the Year. The withdrawal of municipalities and the state from providing local services in rural areas is represented as a self-evident process, and the role of village associations in maintaining those services is constructed as the only option.

Villagers have to take the responsibility into their own hands and start to produce services by themselves. (Bulletin 3/2006: 11)

The representations of ideal rural communities entail an assumption that securing local services is possible for all communities if they are active and work hard enough. By showing positive examples of how to arrange local services through village action, the representations of ideal rural communities justify the transfer of responsibility for providing services from the public sector to individual citizens.

The most prominent sign of a declining village is the loss of inhabitants. Ideal rural communities want to obtain new residents and they also succeed in obtaining them.

It seemed that wellbeing in the village ended when the factory workers' housing was dismantled in the 1960s. But now Syväniemi has seen a renaissance. New residential areas have risen with new residents. (Bulletin 6/2004)

The prevention of depopulation is an essential criterion for an ideal rural community. From the representations of the winners, the reader gets the impression that depopulation of rural areas can be reversed by local activeness. In addition to attracting new residents, active villages also invite leisure residents, visitors, and tourists. A friendly attitude towards "outsiders" has increased in Finnish villages, which has affected the idea of for whom the local services and events are intended (Kumpulainen 2012). In the new millenium, ideal communities are not expected to work only for their own villagers but also for visitors and leisure residents. This makes villages more open and hospitable places, but it also increases their duties.

\section{Cherishing Cultural Heritage}

Cherishing cultural heritage is one of the Finnish rural policy objectives (The Rural Development Programme 2007-2013 for Mainland Finland), and it has also been an election criterion in the Village of the Year competition already from the beginning.

How have you cherished, recorded and made use of tradition? (The competition questionnaire 1987)

In the portraits of the winners, cultural heritage is connected to local concern about the villages' future, which awakens the need to strengthen common knowledge of local history.

Eskola's residents have realized the value of its history. The engine shed was converted into a village hall in the mid-1980s. The train carriages in the corner of the hall were used in wood transportation. The plays "The Tops of the Rails" and "The Steam Horse is Sighing" written by Arto Ojakankas have told us where the roots of Eskola are, in case someone has happened to forget them. (Bulletin 1/2002) 
The most important task in cherishing cultural heritage is to build a common past for the community, a collective memory (Assmann and Czaplicka 1995). The local "village story" and "roots" are produced through different kinds of practices, for example by writing local history books, organizing village festivals and events, or renovating landscaping and old buildings. Culture ties individuals to the local community; shared meanings and values engage people to cherish and develop their home places (Fischer 2006: 20). This approach also makes local culture an instrument of governing and an essential part of constructing moral subjectivity (Foucault 1997: 63). In the case of ideal rural communities, commitment to the village as a place also means becoming involved in village action and community development work.

When ideal rural communities cherish their local tradition and history, they also represent and build national "Finnish" roots based on rural peasant culture. However, even if there is an emphasis on national tradition, the bond to the village is represented not only as nostalgia related to the past (cf. Bauman 2000), but also as a part of European identity.

As one of the Karelian villages in North Karelia and Kainuu, Mutalahti represents the significant richness of Finnish culture. Securing its future and distinctive development work - like in other preserved Karelian villages - is important for the whole country. It can be called a national obligation in integrating Europe, where the importance of regional and local cultures will be emphasized. (Bulletin 4/1990)

The quote is from the 1990s when Finland joined the European Union (in 1995). It constitutes a clear political statement, in which the positive view towards European integration is presented as the opinion of the entire community. Ideal communities are represented as wanting to be a part of integrating Europe, and critical voices are left out of the stories.

In 2000, SYTY decided to introduce cultural landscape as a new criterion for the selection of the Village of the Year (The First National Village Action Programme 2000-2002: 19), which means that village associations now have more obligations concerning cultural heritage. The role of agriculture as livelihood and employer in rural areas has decreased, and traditional agricultural landscapes have become something to be cherished and sustained for future generations (Heikkilä 2000: 35). Ideal rural communities are expected to maintain the traditional Finnish rural landscape as a part of national identity, constructing an aesthetic background for the peoples' peasant roots (Häyrynen 2005).

The market economy and the logic of money (Rose 1999) have affected the practices concerning cultural heritage.

The Untamala Village Association is often the initiator of active measures, and it takes responsibility for the village residents' quality of life. Untamala has taken steps in the direction of village tourism. The village's antiquity and stories are commoditized as products and events. (Bulletin 5/2006)

Ideal villages are represented as communities that are able to use their tradition as an instrument for fund raising and for building the village's image. Finnish rural policy puts high hopes on rural tourism for improving employment and standard of living in rural areas, with rural tourism manifesting in the role of culture and cultural heritage in the national village action programmes (Kumpulainen 2012). Rural communities are encouraged to practise 
branding and marketing (De San Eugenio-Vela and Barniol-Carcasona 2015), which is reflected in how active villages build the community's public image on the internet or advertise village festivals on a large scale to attract paying customers. The impact of the market economy and the development of information society have brought new tools for rural community development, but at the same time they have meant new duties and goals to fulfil. They also affect the ways of presenting and representing the local past and culture. Cherishing cultural heritage not only signifies digging up the roots, but also constructs them from a certain point of view (Boyarin 1994). The commodification of villages affects which stories and traditions are chosen to present the shared past and culture (Mordue 2001).

\section{Village Spinit}

Ideal rural communities are evaluated not only according to their concrete outcomes or practices, but they must also have a village spirit. The competition questionnaire includes a question about how villagers have built and encouraged the local village spirit.

How has village spirit been created and how is it maintained (promoting a sense of fellowship, increasing affection towards the village and promoting awareness of the village outside the community)? In what ways has community effort been practised and promoted? How has cooperation between different organizations in the village been practised and promoted? (The competition questionnaire 1987)

The word "spirit" suggests that villages have mental and spiritual features. It reflects how villages are represented as subjects with characteristics such as a "soul", "spirit", or "will". The representations of village spirit construct rural communities as moral subjects with their own shared intent.

The Village of the Year, Mutalahti, believes in itself. (Bulletin 4/1990)

In my analysis, I have divided village spirit in two separate elements: place spirit and community spirit. The spirit of place is symbolic in character, whereas community spirit is more social and moral. Together, they form village spirit, which is represented as the heart of local development work. the spirit of place (genius loci) emphasizes the experienced and even mythical dimensions related to a certain place (Nordberg-Schulz 1984).

The Village of the Year 1999, Aska, also has a local myth: a wide variety of stories and memories of Hiltu-Antti, the Aska village's "medicine man". Some of them are probably true, others fabricated and a figment of imagination. But people still remember Antti's grim tricks - Antti Hiltunen was the wise man. (Bulletin 6/1999)

The spirit of place increases awareness of the village amongst "outsiders" as well, and it is something that can be marketed and commodified via strategic planning and development projects. In ideal rural communities, it is constructed especially by village festivals, old buildings, landscape, history, and cultural heritage. 
The village (Juntusranta) is resting in a slight winter torpor. The lake has calmed to become a prisoner of ice, smokes rise leisurely from the chimneys. Life is beating in the shelter of houses. The village road winds its way through the hilly landscape. (Bulletin 6/1996)

In ideal villages, there is also a strong sense of community combined with the symbolic meanings related to the place. Community spirit is represented as a moral commitment to the community and cooperation (Hyyryläinen 2000: 112).

The Village Action Association of Finland elected Jakokoski from the Kontiolahti municipality as the Village of the Year 1998. The jury chose Jakokoski for several reasons: the villagers have the will and competence to cooperate and develop their village broadly according to themes and target groups. In addition, their village action is systematic, persistent and creative, and it takes into account the local conditions and respects traditions. And behind it all is, of course, a strong will and the community spirit. (Bulletin 4/1998)

Community spirit is a manifestation of people's spontaneity and voluntary commitment to develop their village, and it is the basis for active development work. The representations of community spirit and community effort as local tradition construct them as authentic and natural ways of acting in Finnish villages.

"Santtio has traditionally had a strong community spirit. This was already in the days when sailing ships were built. The village has had a strong voluntary fire brigade, a private fishing cooperative, an active association of small farmers, etc. Perhaps because of all this there is a feeling of togetherness, which has taken the village activities forward and allowed us to create quite brave solutions for the development of the village", says Chairman of the Santtio Society Esa Urhonen. (Bulletin 5/1997)

In the representations of ideal rural communities, traditional community effort has been deployed effectively for the use of development projects. According to Herbert-Cheshire (2000), individualism and the values related to community are combined in the rural community development discourse. Active members of communities should have an "individual spirit" and think as innovative entrepreneurs, but at the same time work for the common good. Village spirit combines cultural meanings, local identity, social action, and moral commitment, which makes it an effective instrument of governing. Even if it is not anything concrete that can be seen or measured, it is the most important element in constructing active communities, especially because it is the precondition for local activeness and voluntary strategic development work. Evaluating village spirit means first of all evaluating a community's commitment to take responsibility for its village.

\section{Conclusions}

According to Woods (2005), we are witnessing a "rural reconstruction" by which the traditional role of rural space, based on agriculture, has transformed into a multifunctional rural space where especially the logic of commercialization and consumption defines the meanings and practices of rurality (Pospěch et al. 2015). The ideal model of a rural community is a particular representation of the post-productive countryside reconstructing the role of local 
communities. My results indicate that agriculture as livelihood is no longer a significant part of an ideal rural community, which is consistent with the research on the representation of a good village in the Czech Republic (Pospěch et al. 2015). But in the Finnish case, agriculture is still strongly present at the symbolic level, as especially the rural landscape and local cultural heritage are based on an agricultural past, which is also manifested in the practices of commercializing and marketing rural communities for visitors and tourists.

The symbolic construction of the past in active villages reproduces the rural idyll, i.e. nostalgic and romanticized images related to rurality (Jones 1995; Lagerqvist 2014). According to my results, the rural idyll is a part of the representation of an ideal rural community in two different meanings. Firstly, it is used in the commercialization of villages for tourists and as an element to construct the village image as a special and unique place, the spirit of the place. Secondly, the rural idyll is important especially when building local roots and commitment to participate in community development practices, the village spirit. However, the romanticized past is not represented as the opposite for a developing and future-oriented community, but as an important element in constructing it.

The criteria for defining an ideal rural community have been solidified over the years through the Village of the Year competition, and the general visions for the village action movement, written in the 1970s, essentially still apply today. Strategic planning, development projects, responsibility for local welfare, cherishing cultural heritage, and village spirit are the characteristics that build ideal rural communities, active Finnish villages. There have also been changes within the themes, and the requirements for rural community development work have expanded. Village planning has become more detailed, and there are new fields to be included in village plans. Development projects have become larger and more ambitious, increasing entrepreneurial and strategic practices within community life. Cultural heritage is no longer cherished for the villagers only, but for tourists as well, thus becoming a means to collect money. Responsibility for local services has expanded, especially because of the decline of public services in rural areas.

The changes in the criteria of an ideal rural community are the outcome of the integration of the village action movement with rural policy in the 1990s, but they also reflect wider changes in Finnish society. Neoliberal politics have strengthened in Finland, and instead of the centralized state, there has been an increasing emphasis on the role of the private and third sector in providing welfare for citizens. In rural policy, the activation of communities and individual citizens, i.e. active citizenship politics (Gaynor 2011), is seen as the answer to the weakening of public services and a means to secure welfare in rural areas.

The representation of an ideal rural community reflects the movement of local communities towards post-productive practices and characteristics of rurality (Pospěch et al. 2015), but it also constructs an idealistic concept of local communities as a part of neoliberal governmentality. The combination of strategic development and a nostalgic rural past romanticizes community-based and bottom-up development approaches, and fades power relations and structural problems out of the picture.

In the representation of an ideal rural community, local problems, as well as successes, are constructed as the consequences of communities' own actions and free choices. The communities are represented as community heroes in the portraits published by SYTY; they are 
brave fighters who have saved their communities from decline and brought them back to life. In the 22 years of the competition, the nature of the fight has been seen more and more as one of villages' internal struggles, in other words, as a fight to change local attitudes and atmosphere, and make use of inner resources. The success of a village is not achieved by protesting against local officers or politicians, but by solving local problems and dealing with them with an entrepreneurial attitude. The representation of the ideal rural community produces a model of a self-governing and active community subject which takes moral responsibility for local development and faces challenges by using the community's own capabilities and resources. The images construct a paradoxical assumption that in rural areas even external and structural problems are communities' internal challenges that can be solved through local activeness.

This study contributes to critical discussions of the role of local communities in rural development by pointing to the simultaneously political and romanticized nature of the representation of ideal rural communities. The representation produced by rural policy offers only one pathway to develop villages, namely through active citizenship and the practice of particular community development activities. However, this is a narrow perspective and contradicts the notion of the countryside as a multifunctional space (Woods 2005). Further, the results of this research have revealed only the policy-level representation of a rural community and have excluded local-level representations - and villagers' experiences - of rural communities. In addition, the representation of an ideal rural community presented here has been based on portraits of the most active rural communities in Finland, telling us nothing about the problems and challenges facing average villages. Therefore, the representation of an ideal model revealed by the results cannot serve as a general description of local rural communities.

\section{References}

ASSMANN, Jan and John CZAPLICKA. 1995. "Collective Memory and Cultural Identity." New German Critique 62: 125-133.

BAUMAN, Zygmunt. 2000. Liquid Modernity. Cambridge: Polity Press.

BELL, David. 2006. "Variations of the Rural Idyll." Pp. 149-161 in The Handbook of Rural Studies, edited by Paul CLOKE, Terry MARSDEN and Patrick MOONEY. London: SAGE.

BOYARIN, Jonathan. 1994. "Space, Time and the Politics of Memory." Pp. 1-38 in Remapping Memory: The Politics of TimeSpace, edited by Jonathan BOYARIN. Minneapolis: University of Minnesota Press.

CLOKE, Paul. 1997. "Country Backwater to Virtual Village? Rural Studies and 'The Cultural Turn'." Journal of Rural Studies 13(4): 367-375.

CLOKE, Paul and Jo LITTLE, eds. 1997. Contested Countryside Cultures: Otherness, Marginalisation and Rurality. London: Routledge.

CRUIKSHANK, Barbara. 1999. The Will to Empower: Democratic Citizens and Other Subjects. London: Cornell University Press.

DEAN, Mitchell. 1999. Governmentality: Power and Rule in Modern Society. London: SAGE.

DE SAN EUGENIO-VELA, Jordi de and Montse BARNIOL-CARCASONA. 2015. "The Relationship Between Rural Branding and Local Development: A Case Study in the Catalonia's Countryside: Territoris Serens." Journal of Rural Studies 37: 108-119. 
EVERSOLE, Robyn. 2010. "Remaking Participation: Challenges for Community Development Practice.” Community Development Journal 47(1): 29-41.

FISCHER, Frank. 2006. "Participatory Governance as Deliberative Empowerment: The Cultural Politics of Discursive Space." The American Review of Public Administration 36(1): 19-40.

FOUCAULT, Michel. 1981. The History of Sexuality, Volume 1: An Introduction. Harmondsworth: Penguin Books.

FOUCAULT, Michel. 1997. Ethics: Essential Works of Foucault 1954-1984. London: Penguin Books.

FOUCAULT, Michel. 2002. Essential Works of Foucault 1954-1984, Volume 3: Power. London: Penguin Books.

GAYNOR, Niamh. 2011. "In-Active Citizenship and the Depoliticization of Community Development in Ireland." Community Development Journal 46(1): 27-41.

GORDON, Colin. 1991. "Governmental Rationality: An Introduction.” Pp. 1-48 in The Foucault Effect: Studies in Governmentality, edited by Graham BURCHELL, Colin GORDON and Peter MILLER. Chicago: University of Chicago Press.

GRAY, John. 2000. "The Common Agricultural Policy and the Re-Invention of the Rural in the European Community.” Sociologia Ruralis 40(1): 30-52.

HALFACREE, Keith. 1995. "Talking About Rurality: Social Representations of the Rural as Expressed by Residents of Six English Parishes.” Journal of Rural Studies 11(1): 1-20.

HALFACREE, Keith. 2006. "Rural Space: Constructing a Three-Fold Architecture." Pp. 44-62 in The Handbook of Rural Studies, edited by Paul CLOKE, Terry MARSDEN and Patrick MOONEY. London: SAGE.

HALHEAD, Vanessa. 2004. Suomen kylätoimintaliike \& Euroopan maaseutuliikkeet. Suomen Kylätoiminta ry:n julkaisu 2/2005.

HÄYRYNEN, Maunu. 2005. Kuvitettu maa: Suomen kansallisten maisemakuvastojen rakentuminen. Helsinki: Suomalaisen kirjallisuuden seura.

HEIKKILÄ, Tapio. 2000. Suomalainen kulttuurimaisema. Sulkava: Tammi.

HERBERT-CHESHIRE, Lynda. 2000. "Contemporary Strategies for Rural Community Development in Australia: A Governmentality Perspective.” Journal of Rural Studies 16(2): 203-215.

HERBERT-CHESHIRE, Lynda and Vaughan HIGGINS. 2004. "From Risky to Responsible: Expert Knowledge and Governing of Community-led Rural Development.” Journal of Rural Studies 20(3): 289-302.

HERBERT-CHESHIRE, Lynda, Vaughan HIGGINS and Geoffrey LAWRENCE. 2006. "Introduction: Governing the Rural.” Pp. 1-18 in Rural Governance: International Perspectives, edited by Lynda HERBERT-CHESHIRE, Vaughan HIGGINS and Geoffrey LAWRENCE. London: Routledge.

HYYRYLÄINEN, Torsti. 1994. Toiminnan aika. Tutkimus suomalaisesta kylätoiminnasta. Vammala: Line Sixtyfour.

HYYRYLÄINEN, Torsti. 2000. "Kylätoiminnan perinne sosiaalisena pääomana.” Pp. 109-119 in Eurooppalaistuva maaseutupolitiikka, edited by Torsti HYYRYLÄINEN and Pertti RANNIKKO. Tampere: Vastapaino.

JONES, Owain. 1995. "Lay Discourses of the Rural: Developments and Implications for Rural Studies." Journal of Rural Studies 11(1): 35-49.

JOSEPH, Miranda. 2002. Against the Romance of Community. Minneapolis: University of Minnesota Press.

KEARNS, Adrian J. 1992. "Active Citizenship and Urban Governance." Transactions of the Institute of British Geographers 17(1): 20-34.

KLESSE, Christian. 2007. “'How to be a Happy Homosexual?!' Non-monogamy and Governmentality in Relationship Manuals for Gay Men in the 1980s and 1990s." The Sociological Review 55(3): 571-591. 
KRAWCHENKO, Tamara. 2014. "Bringing Municipalities into Rural Community and Economic Development: Cases from Atlantic Canada." The Journal of Rural and Community Development 9(3): 78-96.

KUMPULAINEN, Kaisu. 2012. Kylätoiminta ja aktiivisen kylän tuottaminen. Jyväskylä: University of Jyväskylä.

LAGERQVIST, Maja. 2014. "The Importance of an Old Rural Cottage: Media Representations and the Construction of a National Idyll in Post-war Sweden." Journal of Rural Studies 36: 33-41.

LITTLE, Jo. 1999. "Otherness, Representation and the Cultural Construction of Rurality." Progress in Human Geography 23(3): 437-442.

MARINETTO, Michael. 2003. "Who Wants to be an Active Citizen? The Politics and Practice of Community Involvement." Sociology 37(1): 103-120.

MORDUE, Tom. 2001. "Performing and Directing Resident/Tourist Cultures in Heartbeat Country." Tourist Studies 1(3): 233-252.

NORDBERG-SCHULZ, Christian. 1984. Genius Loci: Towards a Phenomenology of Architecture. New York: Rizzoli.

OKSA, Jukka. 1998. Syrjäkylä muutoksessa. Joensuun: Joensuun yliopisto.

PERELMAN, Chaim. 1982. The Realm of Rhetoric. London: Notre Dame.

POSPĚCH, Pavel, Daniela SPĚŠNÁ and Adam STAVENÍK. 2015 "Images of a Good Village: A Visual Analysis of the Rural Idyll in the 'Village of the Year' Competition in the Czech Republic." European Countryside 7(2): 68-86.

RAY, Christopher. 2000. “The EU LEADER Programme: Rural Development Laboratory.” Sociologia Ruralis 40(2): 163-171.

ROSE, Nikolas. 1990. Governing the Soul: Shaping of the Private Self. London: Routledge.

ROSE, Nikolas. 1996. Inventing Our Selves: Psychology, Power, and Personhood. New York: Cambridge University Press.

ROSE, Nikolas. 1999. Powers of Freedom: Reframing Political Thought. Cambridge: University Press.

ROSE, Nikolas. 2000. "Community, Citizenship, and the Third Way." American Behavioral Scientist 43(9): 1395-1411.

SJÖBLOM, Stefan and Sebastian GODENHJELM. 2009. "Project Proliferation and Governance - Implications for Environmental Management." Journal of Environmental Policy \& Planning 11(3): $169-185$.

TRIANTAFILLOU, Peter and Mikkel R. NIELSEN. 2001. "Policy Empowerment: The Making of Capable Subjects." History of Human Sciences 14(2): 63-86.

VEPSÄLÄINEN, Mia and Kati PITKÄNEN. 2010. "Second Home Countryside. Representations of the Rural in Finnish Popular Discourses.” Journal of Rural Studies 26(2): 194-204.

WOODS, Michael. 2005. Rural Geography. London: SAGE.

\section{Author}

Kaisu Kumpulainen is a university teacher in the Cultural Policy Master's Degree Programme at the University of Jyväskylä, Finland. She is also the chairperson of the Finnish Society for Rural Research and Development which promotes interaction between rural researchers and developers. Her research focuses on rural community development and resilience, participation and cultural sustainability.

Contact: kaisu.kumpulainen@jyu.fi 